\title{
The Effects of Non-Exclusive Breastfeeding on the Risk of Pneumonia in Children under Five: Meta-Analysis
}

\author{
Putu Anggi Widia Karmany'), Setyo Sri Rahardjo²), Bhisma Murti1) \\ 1)Masters Program in Public Health, Universitas Sebelas Maret \\ 2)Faculty of Medicine, Universitas Sebelas Maret
}

Background: Pneumonia is an inflammation of the lung parenchyma caused by pathogenic microorganisms such as bacteria, viruses, fungi, and parasites that can occur together with lower respiratory tract infections. Pneumonia is the cause of death for more than 800,000 children under five worldwide in 2017. One of the risk factors for pneumonia is a history of breastfeeding (ASI). This study aimed to estimate the effect of non-exclusive breastfeeding on the risk of pneumonia in children under five. Subjects and Method: This meta-analysis was conducted by systematically reviewing similar primary articles from PubMed, Google Scholar, and Springer Link. The articles that were analyzed by the meta-analysis were articles published from 2011 to 2019. PICO compiled the problem formulation: Population: children under five, Intervention: non-exclusive breastfeeding, Comparison: exclusive breastfeeding, Outcome: pneumonia. Keywords for searching articles: "exclusive breastfeeding" OR "breast milk" AND "pneumonia," "exclusive breastfeeding" AND "pneumonia children under five" AND "multivariate" AND "case con- trol." The inclusion criteria used were full paper, used English and Indonesian, and the case-control study design. The results were reported with adjusted odds ratio. Articles were collected using PRISMA diagrams and analyzed using Review Manager 5.3.

Results: A total of 9 primary articles were analyzed using meta-analysis with a total sample size of 2,837 children under five. The metaanalysis of case-control studies showed that non-exclusive breastfeeding increased the risk of pneumonia in children under five $(\mathrm{aOR}=$ 4.00; $95 \% \mathrm{CI}=2.75$ to 5.81 ).

Conclusion: Non-exclusive breastfeeding increases the risk of pneumonia in children under five.

Keywords: non-exclusive breastfeeding, pneumonia, meta-analysis

\section{Correspondence:}

Putu Anggi Widia Karmany. Masters Program in Public Health. Universitas Sebelas Maret, Jl. Ir. Sutami 36A, Surakarta 57126, Central Java. Email: putuanggiwidiakarmany@gmail.com.

Cite this as:

Karmany PAW, Rahardjo SS, Murti B (2020). The Effects of Non-Exclusive Breastfeeding on the Risk of Pneumonia in Children under Five: Meta-Analysis. J Epidemiol Public Health. 05(04): 393-401. https://doi.org/10.26911/jepublichealth.2020.05.04.01.

cc (1) (2) Journal of Epidemiology and Public Healthis licensed under a Creative Commons

Attribution-NonCommercial-ShareAlike 4.0 International License.

\section{BACKGROUND}

The incidence of pneumonia is a world health problem, not only in developing countries but also in developed countries. It is estimated that $70 \%$ of under-five deaths due to pneumonia worldwide occur in developing countries, especially countries in Africa and Southeast Asia (Rasyid, 2013). According to the World Health Organiza- tion (WHO), pneumonia is the leading killer of children under five years of age in the world. This disease caused the death of 808,694 children under 5 years of age in 2017, accounting for $15 \%$ of all deaths of children under the age of five (WHO, 2019). Most of the deaths occurred in children under two years of age, and nearly 153,000 
deaths occurred in the first month of life (UNICEF, 2019).

In 2018, 437,000 children under five died from diarrhea, and 272,000 died from malaria (WHO, 2019). Based on data from the Health Profiles of the Republic of Indonesia in 2018, the number of children under five with pneumonia was 447,431 people, and under-five deaths due to pneumonia were 1,351 people with a Case Fatality Rate (CFR) of $0.30 \%$ (Indonesian Ministry of Health, 2019). In Indonesia, the incidence of pneumonia in children under five is still high, requiring serious attention from the government.

Pneumonia is an inflammation of the lung parenchyma caused by infection with pathogenic microorganisms such as bacteria, viruses, fungi, and parasites that can occur together with lower respiratory tract infections (Dahlan, 2009). The most common causes of pneumonia are bacteria and viruses in the air that are inhaled while breathing. Pneumonia can be transmitted in several ways, including through droplets (from coughing or sneezing), through the blood, especially during or after childbirth, or through contaminated surfaces.

The common causes of pneumonia in children in developing countries are caused by the bacteria Streptococcus pneumonia, Hemophilus influenza, and Staphylococcus aureus (WHO, 2019). Children under five are an age group that is prone to nutrientrelated diseases and other diseases. Children under five must-have protection prevent diseases that can cause growth and development to be disrupted or even cause death (Tanjung et al., 2017).

The risk factors associated with the incidence of pneumonia in children under five include age, sex, nutritional status, low birth weight, immunization status, exclusive breastfeeding, and vitamin A. Exclusive breastfeeding is giving breast milk only to babies without the addition of other fluids such as formula milk, lemon juice, honey, OR water. Breast milk is an emulsion of fat in a protein, lactose, and organic salts solution secreted by the two sides of the mother's breast glands, as the main food for newborns (Sutanto, 2018).

Based on several research results related to the effects of breastfeeding, nonexclusive breastfeeding correlates with the risk of pneumonia in children under five, especially children in developing countries. This study aims to estimate the effect of non-exclusive breastfeeding on the risk of pneumonia in children under five.

\section{SUBJECTS AND METHOD}

\section{Study Design}

This study was a meta-analysis study. Article searches were carried out for one month systematically and comprehensively from databases including PubMed, Google Scholar, and Springer Link. The keywords used were "exclusive breastfeeding" OR "breast milk" AND "pneumonia," "exclusive breastfeeding," AND "pneumonia children under five" AND "multivariate" AND "case control."

\section{Inclusion Criteria}

Articles in English and Indonesian, full-text articles with a case-control study design. The study subjects were children under five. The study results were multivariate data and reported using the adjusted odds ratio (aOR) and pneumonia outcomes.

\section{Exclusion Criteria}

This study's exclusion criteria researched with a non-case control study design, fulltext articles, and published before 2005 . Articles published were in languages other than English and Indonesian.

\section{Operational Definition of Variables}

The article search was carried out by considering the eligibility criteria defined using the PICO model. The study population were 
Karmany et al./ The Effects of Non-Exclusive Breastfeeding on the Risk of Pneumonia

children under five with an intervention in the form of non-exclusive breastfeeding, namely exclusive breastfeeding, and the outcome was pneumonia.

Pneumonia was an inflammatory condition of the lung parenchyma caused by infection with pathogenic microorganisms such as bacteria, viruses, fungi, and parasites that can coincide with lower respiratory tract infections. The study instrument was a questionnaire with a dichotomy measuring scale.

Non-exclusive breastfeeding was defined as providing complementary foods or drinks other than breast milk to a baby before 6 months old. The study instrument was a questionnaire with a dichotomy measuring scale.

\section{Data Analysis}

Articles were collected using PRISMA diagrams and analyzed using the Review Manager 5.3 application by calculating the effect size and heterogeneity to determine which study models were combined to form the final meta-analysis result.

\section{RESULTS}

The process of reviewing articles can be seen in the PRISMA flow diagram. Figure 1. This meta-analysis analyzed 9 primary studies conducted in Asia and Africa. The study quality assessment was carried out quantitatively. This study used the Critical Appraisal Skills Program (CASP) for casecontrol study (Center for Evidence-Based Management, 2014; NHS, 2004; 2006).

\section{a. Non-exclusive Breastfeeding}

Research related to non-exclusive breastfeeding with the risk of pneumonia in children under five consisted of 9 articles originating from two continents, namely the Asian Continent ( 4 articles) and the African Continent (5 articles). All articles proved the association of non-exclusive breastfeeding on the risk of pneumonia in children under five.

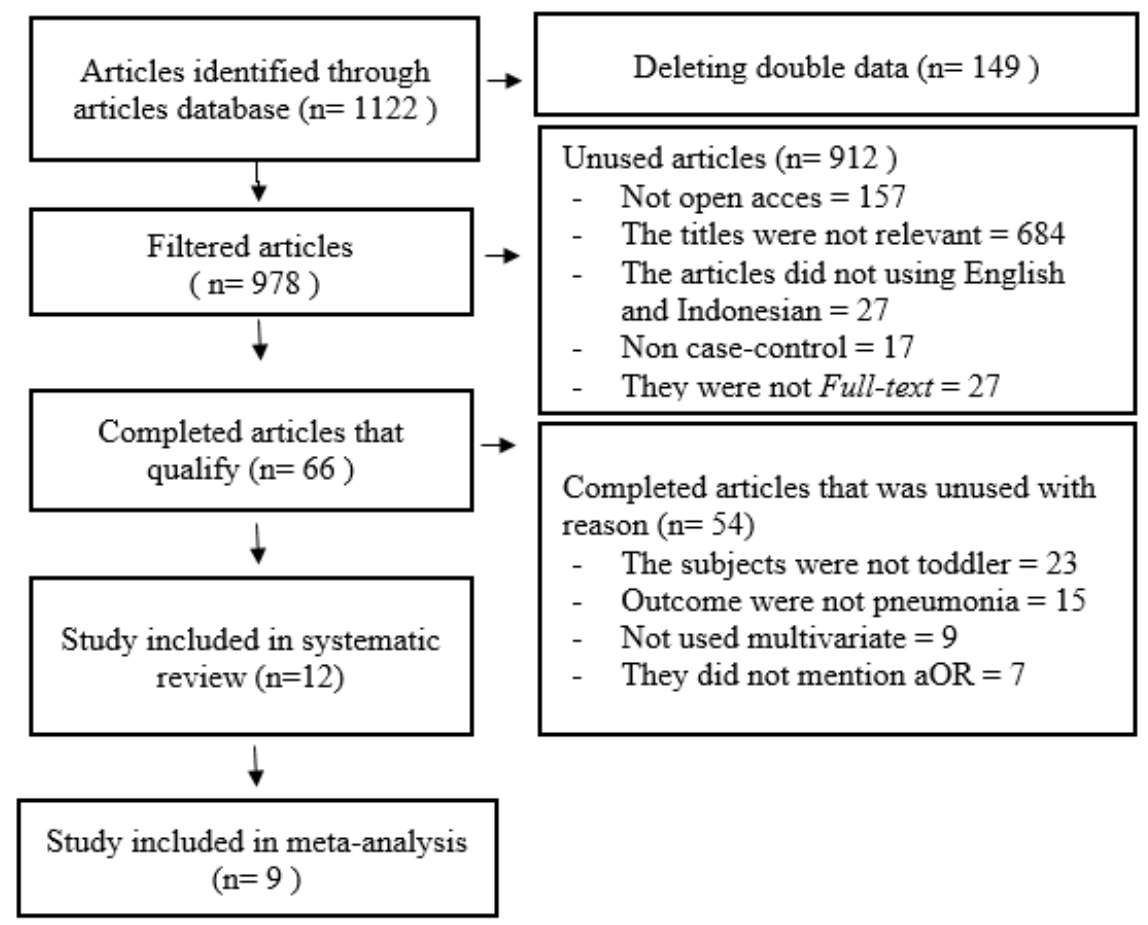

Figure 1. PRISMA flow diagram 
Karmany et al./ The Effects of Non-Exclusive Breastfeeding on the Risk of Pneumonia

Table 1. Quality assessment of the case-control study

\begin{tabular}{|c|c|c|c|c|c|c|c|c|c|c|c|c|c|}
\hline \multirow{2}{*}{ Primary Study } & \multicolumn{13}{|c|}{ Criteria } \\
\hline & $\mathbf{1}$ & 2 & 3 & 4 & 5 & 6 & 7 & 8 & 9 & 10 & 11 & 12 & Total \\
\hline Adawiyah et al. (2016) & 1 & 1 & 1 & 1 & 1 & 1 & O & 1 & 1 & 1 & $\mathrm{O}$ & 1 & 10 \\
\hline Handayani et al. (2016). & 1 & 1 & 1 & 1 & 1 & 1 & $\mathrm{O}$ & 1 & 1 & 1 & $\mathrm{O}$ & 1 & 10 \\
\hline Haryono (2017). & 1 & 1 & 1 & 1 & 1 & 1 & $\mathrm{O}$ & 1 & 1 & 1 & $\mathrm{O}$ & 1 & 10 \\
\hline Nira et al. (2013). & 1 & 1 & 1 & 1 & 1 & 1 & $\mathrm{O}$ & 1 & 1 & 1 & $\mathrm{O}$ & 1 & 10 \\
\hline Geleta et al. (2016). & 1 & 1 & 1 & 1 & 1 & 1 & $\mathrm{O}$ & 1 & 1 & 1 & $\mathrm{O}$ & 1 & 10 \\
\hline Getaneh et al. (2019). & 1 & 1 & 1 & 1 & 1 & 1 & $\mathrm{O}$ & 1 & 1 & 1 & 1 & 1 & 11 \\
\hline Girma \& Berhane (2011) & 1 & 1 & 1 & 1 & O & 1 & O & 1 & 1 & 1 & $\mathrm{O}$ & 1 & 9 \\
\hline Jemal et al. (2018) & 1 & 1 & 1 & 1 & o & 1 & o & 1 & 1 & 1 & o & 1 & 9 \\
\hline Ngocho et al. (2019) & 1 & 1 & 1 & 1 & 1 & 1 & o & 1 & 1 & 1 & 1 & 1 & 11 \\
\hline
\end{tabular}

\section{a. Forest plot}

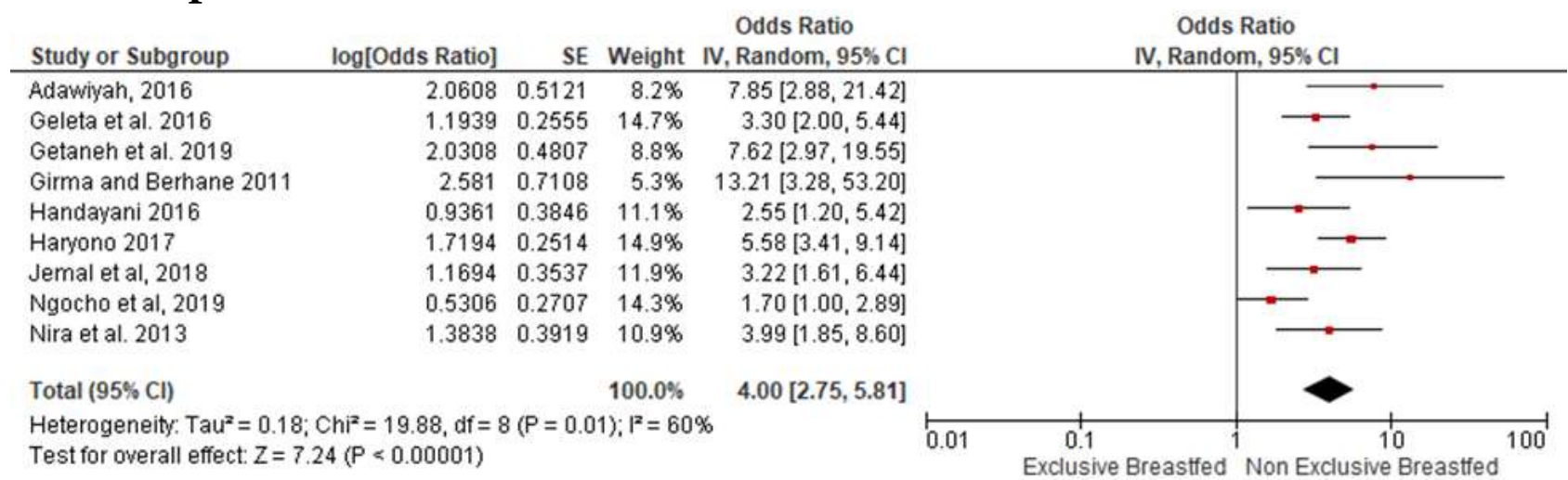

Figure 2. Forest plot of the effect of non-exclusive breastfeeding on the risk of pneumonia in children under five

\section{b. Funnel plot}

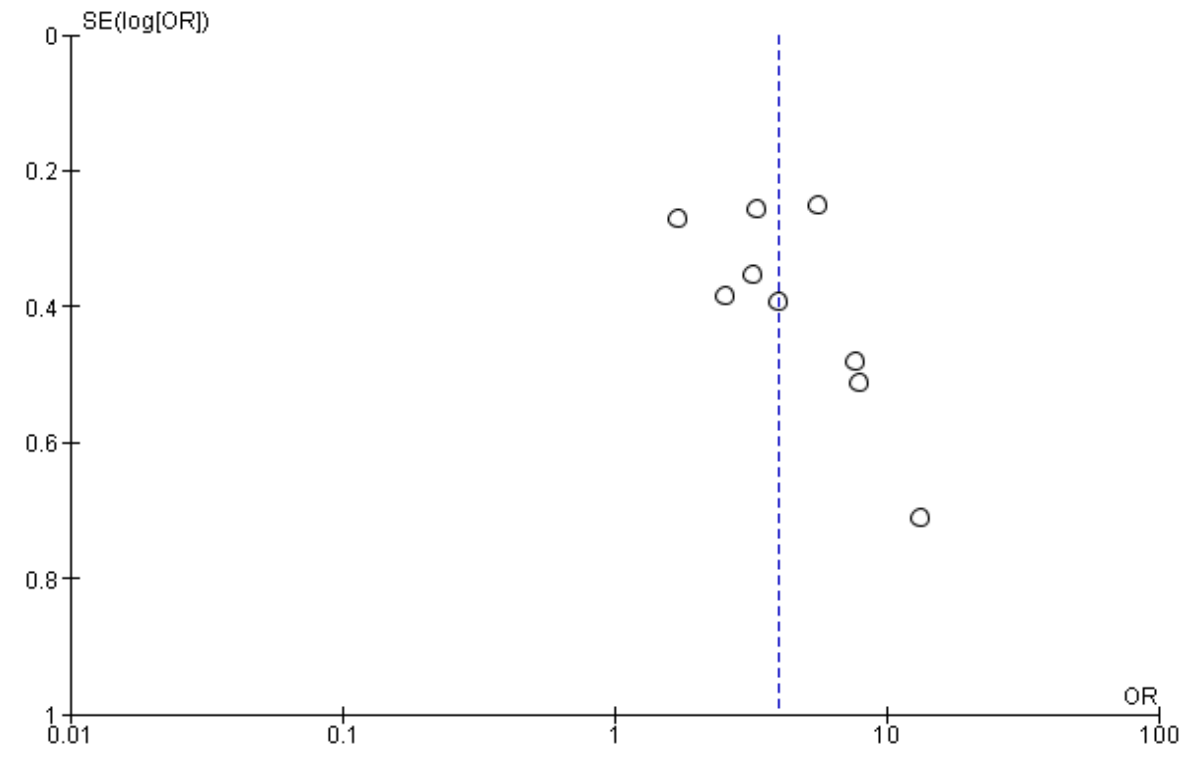

Figure 3. Funnel plot of the effect of non-exclusive breastfeeding on the risk of pneumonia in children under five 
Interpretation of the results from the meta-analysis process can be seen from the forest plot. Figure 4.3 shows that children who were not exclusively breastfed had a 4 times greater risk of pneumonia than children exclusively breastfed with statistical significance $(\mathrm{aOR}=4.00 ; 95 \% \mathrm{CI} 2.75$ to $5.81 ; \mathrm{p}<0.001)$. The study data's heterogeneity showed $\mathrm{I}^{2}=60 \%$, so that the data was declared heterogeneous (random effect model).

The funnel plot (Figure 3) shows a publication bias, which was indicated by the plot's asymmetry on the right and left sides, not forming an inverted funnel. On the right side, 4 plots were located far apart. On the left side, 4 plots were located close together, and there was 1 plot in the middle. The plot on the graph's right appeared to have a standard error (SE) between 0.2 and o.8. The plot on the left of the graph had a standard error (SE) between 0.2 and 0.4. Bias also occurred from the imbalance of the distance between the studies on the right and left of the funnel plot.

\section{DISCUSSION}

This systematic study and meta-analysis study themed the effect of non-exclusive breastfeeding on the risk of pneumonia in children under five. The independent variable analyzed was non-exclusive breast milk. Research that discusses pneumonia is considered important because the incidence rate of pneumonia is still quite high in both children under five in Indonesia and the world.

This systematic study and meta-analysis study uses research that controls confounding factors, which can be seen from the study inclusion criteria, namely multivariate analysis with statistical results reported in the adjusted odds ratio (aOR).

Estimates of non-exclusive breastfeeding's effect on the risk of pneumonia in children under five were processed using the RevMan 5.3 application using the generic inverse variance method. The systematic study results and meta-analysis are presented in the form of a forest plot and a funnel plot.

\section{Non-exclusive breastfeeding on} pneumonia

Forest plot results from study articles with a case-control study design showed that children under five who were not exclusively breastfed had a 4 times greater risk of becoming infected with pneumonia than children under five who were exclusively breastfed $(\mathrm{aOR}=4.00$; 95\% CI 2.75 to 5.81; $\mathrm{p}<0.001)$. This showed that non-exclusive breastfeeding had a statistically significant effect on increasing the risk of pneumonia in children under five.

The results of this study are in line with a study conducted by Sugihartono (2012), which stated that breastfeeding without fluids or other foods for less than 6 months had an 8.9 times greater risk of developing pneumonia compared to children under five who were breastfed for more or the same as 6 months. This study is also supported by a study conducted by Nira et al. (2013), which stated that nonexclusive breastfeeding increases the risk of pneumonia by 3.99 times greater than children under five with exclusive breastfeeding $(\mathrm{aOR}=3.99 ; 95 \% \mathrm{CI}=1.85$ to 8.59$)$.

A meta-analysis study of breastfeeding to reduce the risk of pneumonia morbidity and mortality in children under two years conducted by Lamberti et al. (2013) showed that the estimated relative risk of pneumonia prevalence was higher in infants who were not exclusively breastfed (RR: 5.61; 95\% CI: 1.23 - 25. 53) than in those who were exclusively breastfed. The risk of pneumonia was increased in infants aged 6-23 months who were not breastfed (RR: 1.93; 95\% CI: 1.39 - 2.69). 
Table 3. Descriptions of primary studies included in the meta-analysis

\begin{tabular}{|c|c|c|c|c|c|c|c|}
\hline $\begin{array}{l}\text { Author } \\
\text { (Year) }\end{array}$ & Country & $\begin{array}{c}\text { Study } \\
\text { Design }\end{array}$ & Sample & $\begin{array}{c}\mathbf{P} \\
\text { (Population) }\end{array}$ & $\begin{array}{c}\text { I } \\
\text { (Intervention) }\end{array}$ & $\begin{array}{c}\mathrm{C} \\
\text { (Comparison) }\end{array}$ & $\begin{array}{c}\text { O } \\
\text { (Outcome) }\end{array}$ \\
\hline $\begin{array}{l}\text { Adawiyah et } \\
\text { al. (2016). }\end{array}$ & Indonesia & $\begin{array}{l}\text { Case- } \\
\text { control }\end{array}$ & 130 & $\begin{array}{l}\text { Children aged o- } \\
59 \text { months }\end{array}$ & $\begin{array}{l}\text { Non-exclusive breastfeeding*, } \\
\text { immunization status, provision of } \\
\text { vitamin A, burning smoke }\end{array}$ & $\begin{array}{l}\text { Exclusive breastfeeding }{ }^{*}, \text { com- } \\
\text { plete immunization, complete } \\
\text { vitamin A provision, no burning } \\
\text { smoke }\end{array}$ & Pneumonia \\
\hline $\begin{array}{l}\text { Handayani } \\
\text { et al. } \\
\text { (2012). }\end{array}$ & Indonesia & $\begin{array}{l}\text { Case- } \\
\text { control }\end{array}$ & 174 & $\begin{array}{l}\text { Children aged 1- } \\
59 \text { months }\end{array}$ & $\begin{array}{l}\text { Non-exclusive breastfeeding*, the } \\
\text { maternal knowledge of pneumonia, } \\
\text { the mother's habit of cleaning the } \\
\text { toddler's room is poor. }\end{array}$ & $\begin{array}{l}\text { Exclusive breastfeeding *, the } \\
\text { mother's knowledge of pneumo- } \\
\text { nia is lacking, the habit of clean- } \\
\text { ing the toddler's room is good. }\end{array}$ & Pneumonia \\
\hline $\begin{array}{l}\text { Haryono } \\
(2017)\end{array}$ & Indonesia & $\begin{array}{l}\text { Case- } \\
\text { control }\end{array}$ & 602 & $\begin{array}{l}\text { Children aged 1- } \\
59 \text { months }\end{array}$ & $\begin{array}{l}\text { Non-exclusive breastfeeding *, } \\
\text { nutritional status, weight gain, DPT } \\
\text { immunization }\end{array}$ & $\begin{array}{l}\text { Exclusive breastfeeding }{ }^{*} \text {, poor } \\
\text { nutritional status, normal weight, } \\
\text { complete DPT immunization }\end{array}$ & Pneumonia \\
\hline $\begin{array}{l}\text { Nira et al. } \\
(2013) .\end{array}$ & Indonesia & $\begin{array}{l}\text { Case- } \\
\text { control }\end{array}$ & 210 & $\begin{array}{l}\text { Children aged 2- } \\
60 \text { months }\end{array}$ & $\begin{array}{l}\text { Non-exclusive breastfeeding *, } \\
\text { house ventilation, kitchen fumes, } \\
\text { humidity }\end{array}$ & $\begin{array}{l}\text { Exclusive breastfeeding }{ }^{*} \text {, good } \\
\text { house ventilation, good humidity }\end{array}$ & Pneumonia \\
\hline $\begin{array}{l}\text { Geleta et al. } \\
(2016) \text {. }\end{array}$ & $\begin{array}{l}\text { Southwest } \\
\text { Ethiopia }\end{array}$ & $\begin{array}{l}\text { Case- } \\
\text { control }\end{array}$ & 382 & $\begin{array}{l}\text { Children aged 2- } \\
59 \text { months }\end{array}$ & $\begin{array}{l}\text { Non-exclusive breastfeeding *, } \\
\text { socioeconomic factors, nutritional } \\
\text { status, body weight }\end{array}$ & $\begin{array}{l}\text { Exclusive breastfeeding }{ }^{*} \text {, socio- } \\
\text { economic factors, good nutritional } \\
\text { status, normal birth weight }\end{array}$ & Pneumonia \\
\hline $\begin{array}{l}\text { Getaneh et } \\
\text { al. (2012). }\end{array}$ & $\begin{array}{l}\text { Northwest } \\
\text { Ethiopia }\end{array}$ & $\begin{array}{l}\text { Case- } \\
\text { control }\end{array}$ & 334 & $\begin{array}{l}\text { Children aged 2- } \\
59 \text { months }\end{array}$ & $\begin{array}{l}\text { Non-exclusive breastfeeding *, the } \\
\text { house near the main road, children } \\
\text { cared for by relatives, opening } \\
\text { windows every day }\end{array}$ & $\begin{array}{l}\text { Exclusive breastfeeding }{ }^{*} \text {, home } \\
\text { away from the highway, does not } \\
\text { open windows every day }\end{array}$ & Pneumonia \\
\hline $\begin{array}{l}\text { Girma \& } \\
\text { Berhane } \\
\text { (2011). }\end{array}$ & $\begin{array}{l}\text { Jimma, } \\
\text { Ethiopia }\end{array}$ & $\begin{array}{l}\text { Case- } \\
\text { control }\end{array}$ & 296 & $\begin{array}{l}\text { Children aged 2- } \\
59 \text { months }\end{array}$ & $\begin{array}{l}\text { Non-exclusive breastfeeding *, } \\
\text { economic status, vaccination status }\end{array}$ & $\begin{array}{l}\text { Exclusive breastfeeding * lack of } \\
\text { economic status, incomplete } \\
\text { vaccination status }\end{array}$ & Pneumonia \\
\hline $\begin{array}{l}\text { Jemal et al. } \\
(2016)\end{array}$ & $\begin{array}{l}\text { Oromiya, } \\
\text { Ethiopia }\end{array}$ & $\begin{array}{l}\text { Case- } \\
\text { control }\end{array}$ & 246 & $\begin{array}{l}\text { Children aged 2- } \\
59 \text { months }\end{array}$ & $\begin{array}{l}\text { Non-exclusive breastfeeding *, } \\
\text { malnutrition, cooking with fire- } \\
\text { wood, house occupants }>5 \text { people }\end{array}$ & $\begin{array}{l}\text { Exclusive breastfeeding*, good } \\
\text { nutrition, household }<5 \text { people }\end{array}$ & Pneumonia \\
\hline $\begin{array}{l}\text { Ngocho et } \\
\text { al. (2013). }\end{array}$ & Tanzania & $\begin{array}{l}\text { Case- } \\
\text { control }\end{array}$ & 463 & $\begin{array}{l}\text { Children aged 1- } \\
59 \text { months }\end{array}$ & $\begin{array}{l}\text { Non-exclusive breastfeeding *, } \\
\text { underweight, kitchen smoke, low } \\
\text { income. }\end{array}$ & $\begin{array}{l}\text { Exclusive breastfeeding * } \text {, normal } \\
\text { body weight, adequate income }\end{array}$ & Pneumonia \\
\hline
\end{tabular}

*Variables included in the meta-analysis 
A meta-analysis study on exclusive breastfeeding was also conducted by Abate et al. (2020). This review aimed to estimate the national prevalence and factors associated with neonatal sepsis in East Africa. The results showed that eleven studies found a significant correlation between non-exclusive breastfeeding and pneumonia in children under five. Children who are not exclusively breastfed have a higher risk of pneumonia than children who are exclusively breastfed at the first six months.

This situation may be due to low or weak body immunity because exclusive breastfeeding and vaccination are strategies to increase children's immunity and prevent infection in children. Thus, children who are not exclusively breastfed and/or not vaccinated will have weak immunity and a greater chance of contracting infections, including pneumonia (Abate et al. 2020).

The risk of infant death who are not exclusively breastfed is also higher than that of infants exclusively breastfed. These results supported the WHO recommendation for exclusive breastfeeding for the first six months and continued breastfeeding for 18 months after that (Lamberti et al., 2013).

Exclusive breastfeeding is recommended within 6 months of the beginning of a baby's life. After 6 months of age, the baby must be introduced to complementary foods, but breastfeeding must be given until the baby is 2 years old (Nira 2013). Breast milk is an ideal nutrient to support babies' optimal health, growth, and development (Anindya, Salimo, and Dewi, 2020). Children who are only breastfed for between 4 and less than 6 months have a greater risk of developing pneumonia than children who are exclusively breastfed for up to 6 months or more (Chantry et al. In Handayani, 2016). In addition, exclusive breastfeeding can reduce infant mortality due to various diseases that attack children, such as pneumonia and diarrhea, and accelerate postpartum recovery for mothers (Haryono et al., 2017).

Based on Government Regulation Number 33 of 2012 concerning exclusive breastfeeding, the government has established a national policy related to exclusive breastfeeding programs, carried out advocacy and dissemination of exclusive breastfeeding programs, and fostered, supervised, and evaluated the implementation and achievement of the Exclusive Breastfeeding Program in Health Care Facilities health education, workplaces, public facilities, and community activities. In addition, the government also provides access to information and education on the implementation of exclusive breastfeeding, so it is hoped that every baby can receive exclusive breastfeeding for the first 6 months of their life so that the risk of pneumonia and other infectious diseases can be reduced. Good knowledge of exclusive breastfeeding can motivate mothers to have a strong desire to breastfeed their babies as early as possible and continue giving exclusive breastfeeding until 6 months (Handajani et al., 2018).

The meta-analysis of 9 case-control studies concluded that children under five who were not exclusively breastfed had a fourfold risk of developing pneumonia compared with children under five who were exclusively breastfed and were statistically significant $(\mathrm{aOR}=4.00 ; 95 \% \mathrm{CI}=$ 2.75 to 5.81 ; $<<0.001$ ).

\section{AUTHOR CONTRIBUTION}

Putu Anggi Widia Karmany was the main researcher who chosethe topics, tracked, and collected research data. Setyo Sri Rahardjo and Bhisma Murti played a role in analyzing data and reviewing research documents. 
Karmany et al./ The Effects of Non-Exclusive Breastfeeding on the Risk of Pneumonia

\section{CONFLICT OF INTEREST}

There was no conflict of interest in this study.

\section{FUNDING AND SPONSORSHIP}

This study used private funds from the mainresearcher.

\section{ACKNOWLEDGEMENT}

The researchers would like to express their gratitude to PubMed, Springer Link, and Google Scholar.

\section{REFERENCE}

Beletew B, Bimerew M, Mengesha A, Wudu M, Azmeraw M (2020). Prevalence of pneumonia and its associated factors among under five children in East Africa: A systematic review and metaanalysis. BMC Pediatr. 20: 254. https://doi.org/10.1186/s12887-02002083-z.

Anindya IG, Salimo H, Dewi YLR (2020). The association between exclusive breastfeeding, maternal nutritional status, maternal zinc intake, and stunting in infants aged 6 months. J Maternal Child Health. 5(1): 37-49. https://doi.org/10.26911/thejmch.20 20.05.01.05.

Chantry CJ, Howard CR, Auinger P (2006). Full breastfeeding duration and associated decrease in respiratory tract infection in US children. Pediatrics. 117(2): 425-32. https://doi.org/10.1542/peds.2004-2283.

Dahlan Z (2009). Buku Ajar Ilmu Penyakit Dalam Edisi V. 5th ed. ed. Sudoyo AW. Jakarta: Pusat Penerbitan Departemen Ilmu Penyakit Dalam Universitas Indonesia.

Handajani DO, Pamungkasari EP, Budihastuti UR (2018). Effectiveness of health promotion by Indonesian Breastfeeding Association in increasing exclusive breastfeeding coverage in Surabaya City, East Java. J Health Promot Behav. 03(01): 1-15. https://doi.org/10.26911/thejhpb.2018.03.01.01.

Kemenkes RI (2019). Data dan informasi profil kesehatan Indonesia 2018. eds. Kurniawan R, Hardhana B, Yudianto, Siswanti T. Jakarta: Kementerian Kesehatan Republik Indonesia.

Lamberti LM, Zakarija-Grković I, Walker CLF, Theodoratou E, Nair H, Campbell H, Black RE (2013). Breastfeeding for reducing the risk of pneumonia morbidity and mortality in children under two: A systematic literature review and meta-analysis. BMC Public Health. 13(3): S18. https://doi.org/10.1186/1471-2458-13-s3-s18.

Murti B (2018). Prinsip dan metode riset epidemiologi. $5^{\text {th }}$ ed. Karanganyar: Bintang Fajar Offset.

Nira NK, Pramono D, Naning R (2013). Risk factors of pneumonia among under five children in Purbalingga District, Central Java Province. Trop Med J. 3(2). https://doi.org/10.22146/tmj.5864.

Rasyid Z (2013). Faktor-faktor yang berhubungan dengan kejadian pneumonia anak balita di RSUD Bangkinang Kabupaten Kampar. Jurnal Kesehatan Komunitas 2(3): 136-40. Doi: 10.25311/jkk.Vol2.Iss3.61.

Sugihartono S, Rahmatullah P (2012). Analisis faktor risiko kejadian pneumonia pada balita di wilayah kerja Puskesmas Sidorejo Kota Pagar Alam. Jurnal Kesehatan Lingkungan Indonesia. 11 (1): 82-86. https://doi.org/10.14710/jkli.11.1.82-86.

Sutanto, Vita A (2018). Asuhan kebidanan nifas \& menyusui. Bantul: PT. Pustaka Baru.

Tanjung WW, Batubara NS, Siregar PK (2017). Faktor-faktor risiko yang ber- 
Karmany et al./ The Effects of Non-Exclusive Breastfeeding on the Risk of Pneumonia

pengaruh terhadap kejadian pneumonia pada balita di Rumah Sakit Tentara Nasional Indonesia Angkatan Darat (TNI-AD) Kota Padangsidimpuan. Jurnal Kesehatan Ilmiah Indonesia (Indonesian Health Scientific Journal). 2(3): 1-10. http://jurnal.unar.ac.id/index.php/health/article/vie $\mathrm{w} / 33$.

Unicef (2019). One child dies of pneumonia every 39 seconds, agencies warn. Retrieved from https://www.unicef.org/indonesia/press-releases/one-child-dies-pneumonia-every-39-seconds-agencies-warn.

WHO (2019). Pneumonia. Retrieved from https://www.who.int/news-room/fac.sheets/detail/pneumonia (July 16, 2020). 